\title{
Ecological assessment of the lake ecosystem sustainability as exemplified by Lake Gorkoye (Chelyabinsk Region)
}

\author{
Alfira Sibirkina ${ }^{1, *}$, Sergey Likhachev ${ }^{1}$, Dmitry Dvinin ${ }^{1}$, Georgiy Voitovich ${ }^{1}$, Lyubov \\ Trofimova ${ }^{1}$, Lada Markova ${ }^{1}$, and Oksana Mulyukova ${ }^{1}$ \\ ${ }^{1}$ Chelyabinsk State University, 129, Kashirin Brothers Str., 454001, Chelyabinsk, Russia
}

\begin{abstract}
The article is devoted to the assessment of the ecological sustainability of Lake Gorkoye in the Chelyabinsk region (Russia). The condition of aquatic ecosystems in industrial regions is mainly determined by the impact on them of anthropogenic factors. The ecological assessment of Lake Gorkoye was carried out according to organoleptic and hydrochemical indicators. The conducted physical and chemical analysis of water in Lake Gorkoye allows stating that water $\mathrm{pH}$ characterizes water as slightly alkaline and alkaline, water saturation with dissolved oxygen is within the norm for water fishery use. The excess of the norms of ammonium cations and nitrite ions, with normal levels of phosphate and nitrate ions, suggests that water in Lake Gorkoye belongs to the dirty water class, which is confirmed by the calculated ratio of nitrite-ions and ammonium cations (1.00:9.69). The revealed COD/BOD ratio is equal to 2.09, indicating that the biological purification process cannot fully occur. Lake Gorkoye is in an unstable state directly caused by business activities in the surrounding area.
\end{abstract}

\section{Introduction}

Lakes are an essential component of the hydrosphere [1]. More than half of all lakes In Russia are located in the Ural Federal District [2]. The Chelyabinsk Region is rich in lakes, many of which are natural hydrological monuments of regional significance, including Lake Gorkoye (decision of the Executive Committee of the Chelyabinsk Regional Council of People's Deputies of January 21, 1969, No. 29 "On the protection of natural sanctuary in the region"). The status of a specially protected natural area allowed protecting the recreational object that is significant for the region from pollution and complete destruction and preserving the unique healing properties of its resources. Lake Gorkoye is famous for its alkaline waters and mineral mud, which are valuable for treatment. The bottom sediments are represented by mineral mud, the reserves of which amount to more than 200 thousand $\mathrm{m} 3$. At present, the balneal re-sources of the lake are used by local residents, vacationers, and tourists of Chelyabinsk and neighboring regions; there-fore, the risk of pollution exists, and comprehensive monitoring of water quality is required. The obtained data on the ecological condition of the aquatic ecosystem of Lake Gorkoye, in the case of possible deterioration of

\footnotetext{
*Corresponding author: sibirkina_alfira@mail.ru
} 
the ecological situation, can serve as a basis for ecological monitoring studies. At present, water quality and the state of ecosystems of surface water bodies in the world are mainly determined by the impact of anthropogenic factors. Among them, the most significant factor is pollution [3].

In accordance with the above, the primary purpose of the work is to conduct an environmental assessment of Lake Gorkoye according to organoleptic and hydrochemical indicators to obtain timely and comprehensive information about the state of the specially protected natural area and to develop recommendations for improving its eco-logical condition.

\section{Materials and methods}

Lake Gorkoye is located in the upper part of the Tobol River basin in the area of the TransUral peneplain within the boundaries of the Uvelsky District, 80 kilometers from the city of Chelyabinsk (Chelyabinsk Region. At-las/ed. by Prof. V. V. Latyushina. - 3rd ed., revised Chelyabinsk: Abris, 2010. -32 p.). The total area of the specially protected natural area is 52.54 hectares. The border is set according to the water cut taken from the state topographic maps M 1:25,000 as of 2000 and equal to 198.8 meters in the Baltic elevation system. The total length of the border of the natural sanctuary is $4.23 \mathrm{~km}$ (http://www.oopt174.ru).

The control sampling stations are shown in Figure 1. Samples were collected for analysis monthly between May and October 2020. Two permanent control sampling stations were installed on the reservoir. The stations were located in opposite coastal parts of the lake. Samples at the stations were taken from the surface water layer.

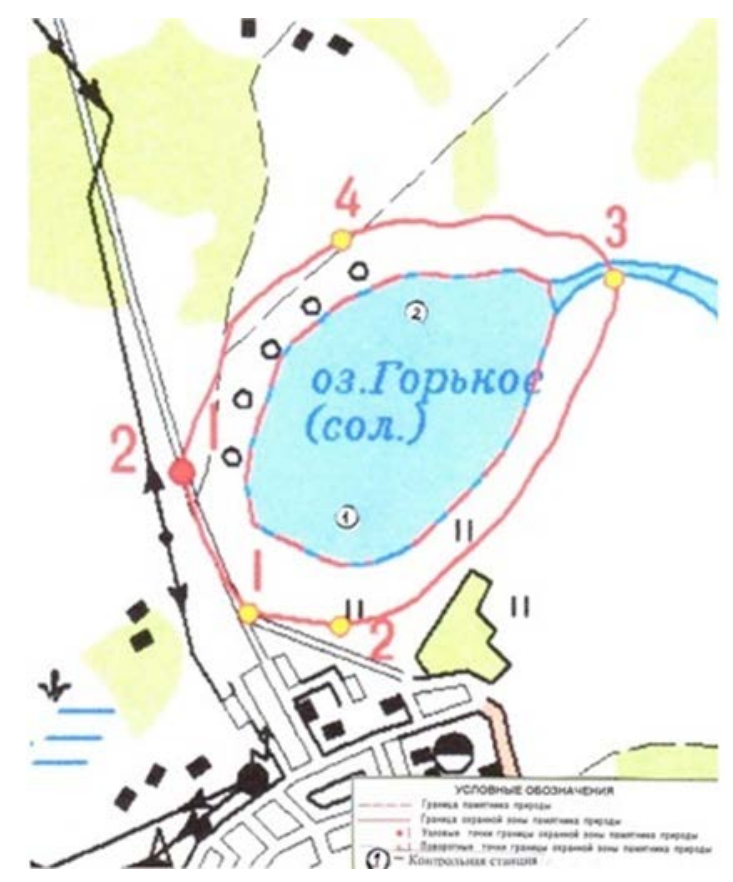

Fig. 1. Control sampling stations on Lake Turgoyak.

Coordinates of the sampling stations SS1 and SS2:

SS 1 - 54³3' $56.774^{\prime} \mathrm{N}, 61^{\circ} 25^{\prime} 19.851^{\prime} \mathrm{E}$

SS $2-54^{\circ} 33$ ' $35.966^{\prime} \mathrm{N}, 61^{\circ} 26^{\prime} 14.86^{\prime} \mathrm{E}$ 
Hydrochemical samples were taken with a fluoroplastic sampler under GOST 17.1.3.0782 "Nature protection. Hydrosphere. Rules for water quality control of reservoirs and watercourses".

The analysis of water samples for hydrochemical indicators was carried out in the accredited center of the Ural Integrated Laboratory of Industrial and Civil Construction Limited Liability Company (hereinafter referred to as UralStroyLab LLC) under the "Federal list of measurement methods approved for use in the field of environmental pollution monitoring" (RD 52.18.595 - 96).

The analysis for hydrological and organoleptic indicators was carried out in the Laboratory of Environmental Monitoring of the Faculty of Ecology of Chelyabinsk State University.

\section{Results}

The thermal regime is one of the most important for the aquatic ecosystem [4]. Gorkoye is a stratified lake. In May, the heating of the surface layers of water averaged $14.9{ }^{\circ} \mathrm{C}(14.6-$ $\left.15.1^{\circ} \mathrm{C}\right)$; in the summer months, there is a natural increase in water temperature with a maximum in July of $27.8^{\circ} \mathrm{C}\left(27.5-28.1^{\circ} \mathrm{C}\right)$; in August, the temperature begins to drop below the levels of June by $4.5^{\circ} \mathrm{C}$, and in October, there is a temperature minimum of $7.3^{\circ} \mathrm{C}(7.0$ $\left.7.6{ }^{\circ} \mathrm{C}\right)$. The average semi-annual water temperature in the lake is $17.3{ }^{\circ} \mathrm{C}$; the minimum temperatures are recorded in October to $7.0^{\circ} \mathrm{C}$, and the maximum in July to $28.1^{\circ} \mathrm{C}$ (Figure 2).

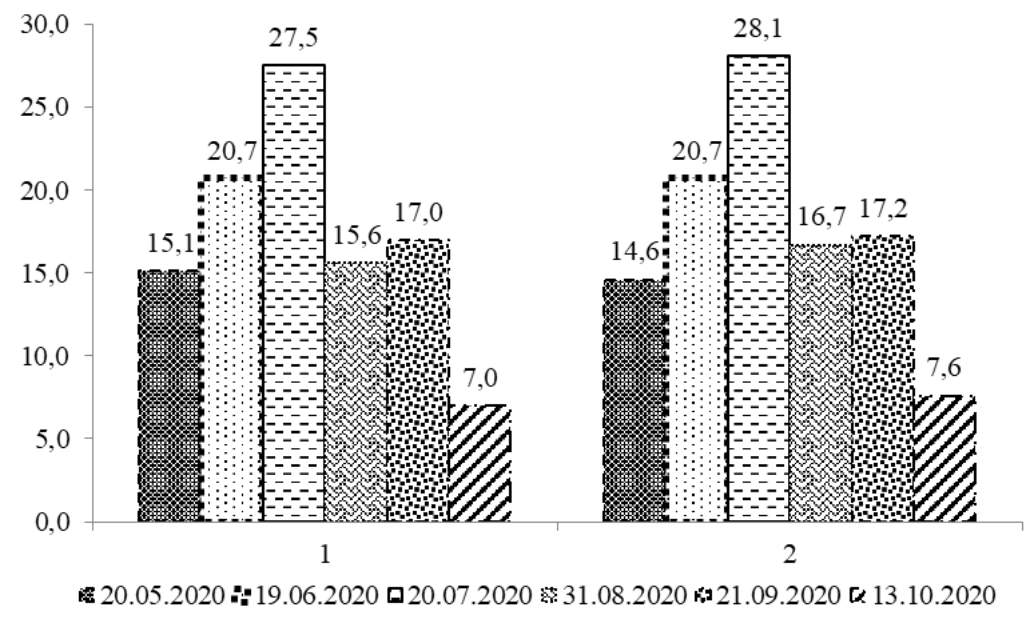

Fig. 2. Surface layer water temperature dynamics in 2020 by sampling points, ${ }^{\circ} \mathrm{C}$.

The ability of water to pass light rays into the depths depends on its transparency, and it is a value that indirectly indicates the number of suspended particles and colloids in water [5]. Reducing the light flux reduces the efficiency of photosynthesis and the biological productivity of the watercourse. Water, depending on the degree of transparency, is conditionally divided into transparent ( $>30$ ), slightly turbid ( $>25$ to 30 ), medium turbidity ( $>20$ to 25 ), turbid ( $>10$ to 20 ), and very turbid $(<10)$. In the course of the study, it was found that water transparency changed not only by months but also by sampling points of the same period. In May (SS No.1), June (SS No. 2), July, August, and October, transparency corresponded to $30 \mathrm{~m}$, i.e., was classified as slightly turbid, in May (SS No. 2) and June (SS No. 1) - turbid, in September at two sampling points it was 8.8 (8.0-9.5) - very turbid (Table 
1). The change in transparency is due to natural reasons; in May, after the ice melts, and in autumn, starting from the end of August, the least transparency of the water is observed. The minimum transparency in spring and autumn depends on the mass development and death of phytoplankton and the entry of allochthonous suspensions into the water during ice melting and intense precipitation. An important role is played by spring and autumn homeothermy, promoting mixing and removing precipitation into the water layer [1].

Table 1. Water transparency in Lake Gorkoye, May-October 2020.

\begin{tabular}{|c|c|c|c|c|c|c|}
\hline $\begin{array}{c}\text { SS } \\
\text { No. }\end{array}$ & $\begin{array}{c}\text { May 20, } \\
\mathbf{2 0 2 0}\end{array}$ & $\begin{array}{c}\text { June 19, } \\
\mathbf{2 0 2 0}\end{array}$ & $\begin{array}{c}\text { July 20, } \\
\mathbf{2 0 2 0}\end{array}$ & $\begin{array}{c}\text { August 31, } \\
\mathbf{2 0 2 0}\end{array}$ & $\begin{array}{c}\text { September } \\
\mathbf{2 1 , 2 0 2 0}\end{array}$ & $\begin{array}{c}\text { October 13, } \\
\mathbf{2 0 2 0}\end{array}$ \\
\hline 1 & 30.0 & 16.5 & 30.0 & 30.0 & 8.0 & 30.0 \\
\hline 2 & 14.5 & 30.0 & 30.0 & 30.0 & 9.5 & 30.0 \\
\hline Mean & 22.3 & 23.3 & 30.0 & 30.0 & 8.8 & 30.0 \\
\hline
\end{tabular}

Besides, the transparency of water depends on its color, and the water color in 2020 varied on average from $42.8^{\circ}$ to $127.3^{\circ}$ (the average for the entire period is $69.2^{\circ}$ ) (Figure 3), and in all sampling periods did not meet the hygienic standards (no more than 30 ), the excess was up to $42.7-324.3 \%$. The water color is mainly due to the presence of humus substances and trivalent iron compounds [6] and can be the first sign of a dangerous situation - deteriorates the physical properties of water, leads to extraneous odors, harms the development of aquatic plant and animal organ-isms as a result of a sharp decrease in the concentration of dissolved oxygen in water, which is used to oxidize iron compounds and humus substances [7].

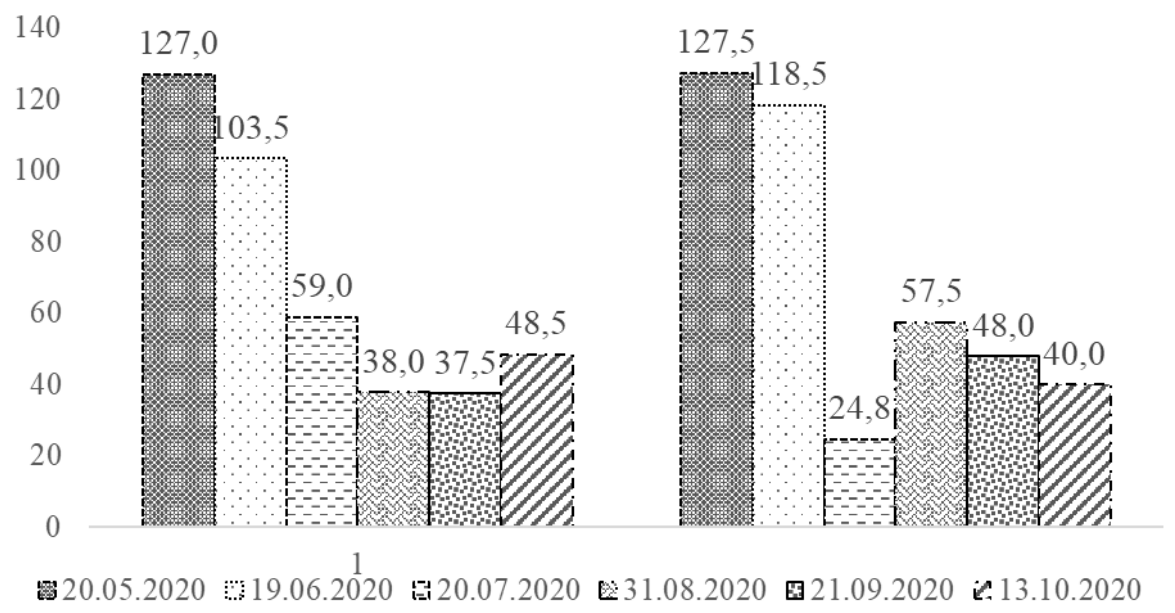

Fig. 3. Dynamics of surface layer water color in 2020 , in ${ }^{\circ}$.

Medium reaction $(\mathrm{pH})$ affects the transformation processes of various forms of nutrients, changes the toxicity of pollutants, affects the chemical processes and activities of aquatic plants and animals, decomposition processes of dying organisms, solubility of minerals. The $\mathrm{pH}$ range is vital for biological objects since each species can only live in a specific $\mathrm{pH}$ range; for example, for carp, the $\mathrm{pH}$ limits are 4.5-10.8 [6]. It was found that the lake water $\mathrm{pH}$ is on average 8.68 (8.4 to 9.0 ), refers to slightly alkaline and alkaline waters, and the saturation of the lake water with dissolved oxygen was $7.84-8.45 \mathrm{mg} / \mathrm{dm}^{3}$ (Table 2). 
Table 2. The main hydrochemical parameters of Lake Gorkoye, May-October 2020.

\begin{tabular}{|c|c|c|c|c|c|}
\hline \multirow{2}{*}{$\begin{array}{l}\text { Concen } \\
\text { tration }\end{array}$} & \multirow{2}{*}{$\begin{array}{c}\text { Unit of } \\
\text { measure }\end{array}$} & \multirow{2}{*}{ Month } & \multicolumn{2}{|c|}{ Sampling station } & \multirow{2}{*}{$\begin{array}{c}\begin{array}{c}\text { Fishery } \\
\text { standard }\end{array} \\
\end{array}$} \\
\hline & & & SS 1 & $S S 2$ & \\
\hline \multirow{6}{*}{$\mathrm{pH}$} & \multirow{6}{*}{ pH units } & May 20, 2020 & $8.8 \pm 0.2$ & $8.9 \pm 0.2$ & \multirow{6}{*}{$6.0-9.0$} \\
\hline & & June 19,2020 & $8.7 \pm 0.2$ & $8.9 \pm 0.2$ & \\
\hline & & July 20,2020 & $9.0 \pm 0.2$ & $9.0 \pm 0.2$ & \\
\hline & & August 31,2020 & $8.5 \pm 0.2$ & $8.3 \pm 0.2$ & \\
\hline & & $\begin{array}{c}\text { September } 21, \\
2020\end{array}$ & $8.5 \pm 0.2$ & $8.4 \pm 0.2$ & \\
\hline & & October 13,2020 & $8.5 \pm 0.2$ & $8.7 \pm 0.2$ & \\
\hline \multirow{6}{*}{$\begin{array}{c}\text { Dissolve } \\
\mathrm{d} \\
\text { oxygen }\end{array}$} & \multirow{6}{*}{$\mathrm{mg} / \mathrm{dm}^{3}$} & May 20,2020 & $7.93 \pm 1.27$ & $7.95 \pm 1.27$ & \multirow{6}{*}{$\begin{array}{c}\text { Not lower } \\
\text { than } 4.0\end{array}$} \\
\hline & & June 19,2020 & $7.86 \pm 1.26$ & $7.92 \pm 1.27$ & \\
\hline & & July 20,2020 & $7.84 \pm 1.25$ & $7.89 \pm 1.26$ & \\
\hline & & August 31,2020 & $7.84 \pm 1.25$ & $7.87 \pm 1.26$ & \\
\hline & & $\begin{array}{c}\text { September } 21 \text {, } \\
2020\end{array}$ & $7.85 \pm 1.26$ & $7.87 \pm 1.26$ & \\
\hline & & October 13,2020 & $8.24 \pm 1.32$ & $8.45 \pm 1.35$ & \\
\hline \multirow{6}{*}{$\mathrm{BOD}_{5}$} & \multirow{6}{*}{$\underset{\mathrm{dm}^{3}}{\mathrm{mgO}_{2} /}$} & May 20,2020 & $10.15 \pm 1.32$ & $8.96 \pm \mathbf{1 . 1 6}$ & \multirow{6}{*}{$\begin{array}{l}\text { No more } \\
\text { than } 2.0\end{array}$} \\
\hline & & June 19,2020 & $8.66 \pm 1.13$ & $11.05 \pm 1.44$ & \\
\hline & & July 20,2020 & $12.84 \pm 1.67$ & $8.66 \pm 1.13$ & \\
\hline & & August 31,2020 & $8.96 \pm 1.16$ & $13.74 \pm 1.79$ & \\
\hline & & $\begin{array}{c}\text { September } 21, \\
2020\end{array}$ & $8.94 \pm 1.16$ & $13.72 \pm 1.79$ & \\
\hline & & October 13,2020 & $11.65 \pm 3.03$ & $2.33 \pm 0.89$ & \\
\hline \multirow{6}{*}{$\begin{array}{c}\text { Perman } \\
\text { ganate } \\
\text { index }\end{array}$} & \multirow{6}{*}{$\begin{array}{l}\mathrm{mgO}_{2} / \\
\mathrm{dm}^{3}\end{array}$} & May 20,2020 & $27.20 \pm 2.72$ & $24.00 \pm 2.40$ & \multirow{6}{*}{$\begin{array}{l}\text { Non- } \\
\text { standard }\end{array}$} \\
\hline & & June 19,2020 & $34.40 \pm 3.44$ & $23.20 \pm 2.32$ & \\
\hline & & July 20, 2020 & $3.36 \pm 0.34$ & $4.48 \pm 0.45$ & \\
\hline & & August 31,2020 & $24.00 \pm 2.40$ & $36.80 \pm 3.68$ & \\
\hline & & $\begin{array}{l}\text { September } 21 \text {, } \\
2020\end{array}$ & $23.95 \pm 2.40$ & $36.74 \pm 3.67$ & \\
\hline & & October 13,2020 & $32.00 \pm 3.20$ & $31.20 \pm 3.12$ & \\
\hline \multirow{6}{*}{$\begin{array}{c}\text { Bicarbo } \\
\text { nates }\end{array}$} & \multirow{6}{*}{$\mathrm{mg} / \mathrm{dm}^{3}$} & May 20, 2020 & $994.30 \pm 79.54$ & $1,030.90 \pm 82.47$ & \multirow{6}{*}{$\begin{array}{l}\text { Non- } \\
\text { standard }\end{array}$} \\
\hline & & June 19, 2020 & $\begin{array}{c}1,085.80 \pm 86.8 \\
6\end{array}$ & $1,091.90 \pm 87.35$ & \\
\hline & & July 20, 2020 & $\begin{array}{c}1,073.60 \pm 85.8 \\
9\end{array}$ & $1,073.60 \pm 85.89$ & \\
\hline & & August 31, 2020 & $\begin{array}{c}1,030.90 \pm 82.4 \\
7\end{array}$ & $1,049.20 \pm 83.94$ & \\
\hline & & $\begin{array}{c}\text { September } 21, \\
2020\end{array}$ & $\begin{array}{c}1,032.52 \pm 82.6 \\
0\end{array}$ & $1,052.11 \pm 84.17$ & \\
\hline & & October 13,2020 & $606.68 \pm 48.53$ & $603.42 \pm 48.27$ & \\
\hline \multirow{6}{*}{ Sulfates } & \multirow{6}{*}{$\begin{array}{l}\mathrm{mg} / \\
\mathrm{dm}^{3}\end{array}$} & May 20,2020 & $625.00 \pm 94.0$ & $650.00 \pm 98.0$ & \multirow{6}{*}{$\begin{array}{l}\text { No more } \\
\text { than } 100\end{array}$} \\
\hline & & June 19,2020 & $630.00 \pm 95.0$ & $639.00 \pm 96.00$ & \\
\hline & & July 20,2020 & $571.00 \pm 86.00$ & $700.0 \pm 105.0$ & \\
\hline & & August 31, 2020 & $\begin{array}{c}722.50 \pm 108.4 \\
0\end{array}$ & $610.00 \pm 91.50$ & \\
\hline & & $\begin{array}{c}\text { September } 21, \\
2020\end{array}$ & $\begin{array}{c}728.60 \pm 109.2 \\
9\end{array}$ & $614.20 \pm 92.13$ & \\
\hline & & October 13,2020 & $\begin{array}{c}987.00 \pm 148.1 \\
0\end{array}$ & $877.30 \pm 131.60$ & \\
\hline \multirow{3}{*}{$\begin{array}{c}\text { Chloride } \\
\text { s }\end{array}$} & \multirow{3}{*}{$\mathrm{mg} / \mathrm{dm}^{3}$} & May 20,2020 & $5,140.25 \pm 0.00$ & $5,228.88 \pm 0.00$ & \multirow{3}{*}{$\begin{array}{l}\text { No more } \\
\text { than } 300\end{array}$} \\
\hline & & June 19,2020 & $5,512.48 \pm 0.00$ & $5,547.93 \pm 0.00$ & \\
\hline & & July 20,2020 & $5,849.25 \pm 0.00$ & $5,849.25 \pm 0.00$ & \\
\hline
\end{tabular}




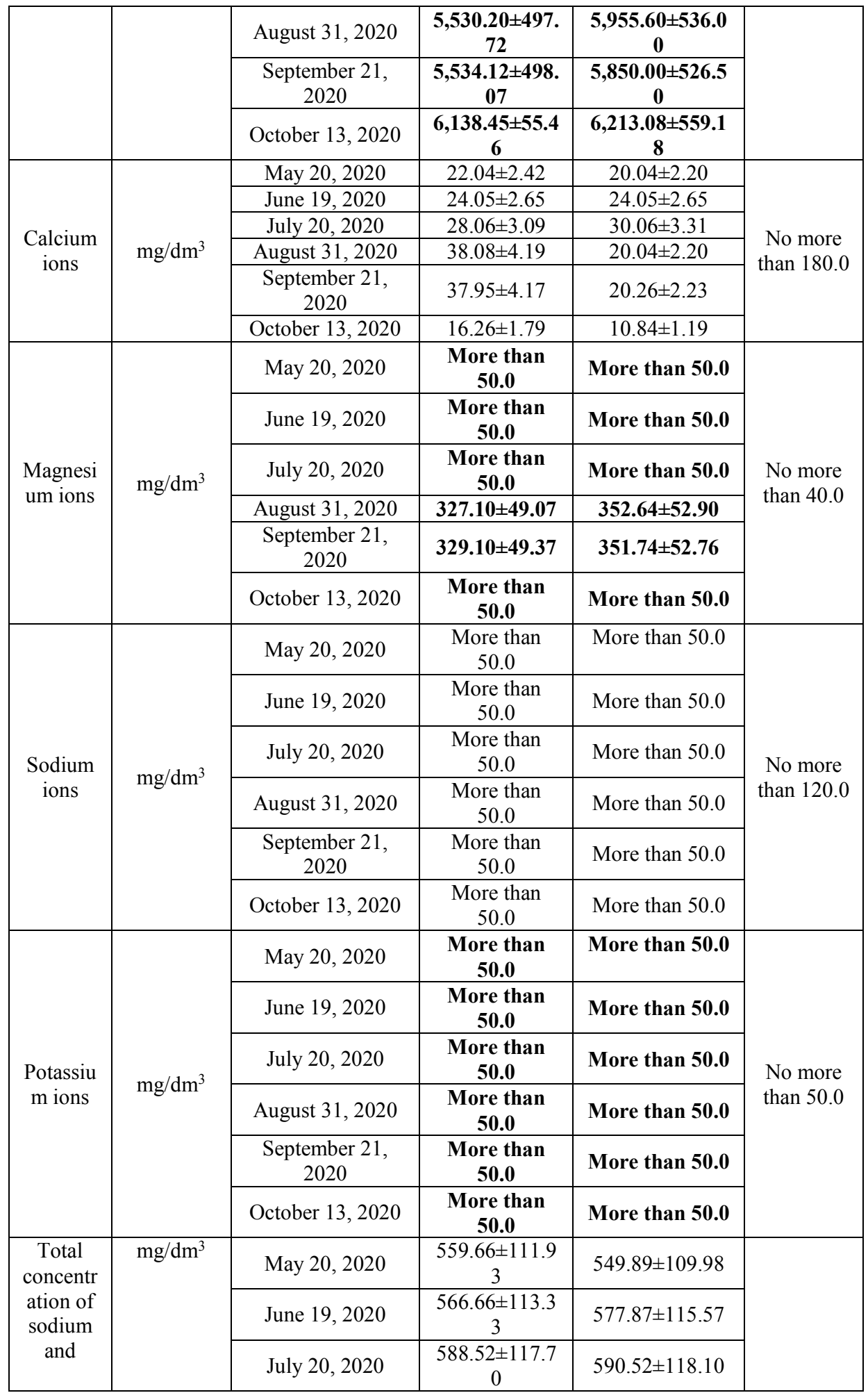




\begin{tabular}{|c|c|c|c|c|c|}
\hline \multirow[t]{3}{*}{$\begin{array}{l}\text { potassiu } \\
\mathrm{m} \text { ions }\end{array}$} & & August 31, 2020 & $\begin{array}{c}3,600.00 \pm 720 . \\
00\end{array}$ & $\begin{array}{c}3,648.00 \pm 729.6 \\
0\end{array}$ & \\
\hline & & $\begin{array}{c}\text { September } 21, \\
2020\end{array}$ & $\begin{array}{c}3,602 \cdot 00 \pm 720 . \\
40\end{array}$ & $\begin{array}{c}3,646.00 \pm 729.2 \\
0\end{array}$ & \\
\hline & & October 13, 2020 & $\begin{array}{c}3,935 \cdot 51 \pm 787 \\
10\end{array}$ & $\begin{array}{c}3,841.16 \pm 768.2 \\
3\end{array}$ & \\
\hline \multirow{6}{*}{$\begin{array}{l}\text { Ammon } \\
\text { ium ion }\end{array}$} & \multirow{6}{*}{$\mathrm{mg} / \mathrm{dm}^{3}$} & May 20, 2020 & $0.30 \pm 0.11$ & $0.41 \pm 0.14$ & \multirow{6}{*}{$\begin{array}{l}\text { No more } \\
\text { than } 1.5\end{array}$} \\
\hline & & June 19,2020 & $\mathbf{2 . 7 0} \pm \mathbf{0 . 5 7}$ & $1.80 \pm 0.38$ & \\
\hline & & July 20, 2020 & $1.60 \pm 0.34$ & $1.00 \pm 0.35$ & \\
\hline & & August 31,2020 & $0.45 \pm 0.16$ & $0.42 \pm 0.15$ & \\
\hline & & $\begin{array}{c}\text { September } 21, \\
2020\end{array}$ & $0.44 \pm 0.15$ & $0.41 \pm 0.14$ & \\
\hline & & October 13,2020 & $2.12 \pm 0.45$ & $2.18 \pm 0.46$ & \\
\hline \multirow{6}{*}{$\begin{array}{l}\text { Nitrite } \\
\text { ion }\end{array}$} & \multirow{6}{*}{$\mathrm{mg} / \mathrm{dm}^{3}$} & May 20,2020 & $0.300 \pm 0.0114$ & $0.421 \pm 0.0105$ & \multirow{6}{*}{$\begin{array}{l}\text { No more } \\
\text { than } 0.08\end{array}$} \\
\hline & & June 19,2020 & $0.027 \pm 0.013$ & $0.028 \pm 0.064$ & \\
\hline & & July 20,2020 & $0.357 \pm 0.089$ & $0.162 \pm 0.062$ & \\
\hline & & August 31,2020 & $0.046 \pm 0.023$ & $0.013 \pm 0.007$ & \\
\hline & & $\begin{array}{c}\text { September } 21, \\
2020\end{array}$ & $0.048 \pm 0.024$ & $0.009 \pm 0.004$ & \\
\hline & & October 13,2020 & $0.006 \pm 0.003$ & $0.010 \pm 0.005$ & \\
\hline \multirow{6}{*}{$\begin{array}{l}\text { Nitrate } \\
\text { ion }\end{array}$} & \multirow{6}{*}{$\mathrm{mg} / \mathrm{dm}^{3}$} & May 20,2020 & $0.10 \pm 0.02$ & $0.16 \pm 0.03$ & \multirow{6}{*}{$\begin{array}{l}\text { No more } \\
\text { than } 40.0\end{array}$} \\
\hline & & June 19,2020 & $0.24 \pm 0.05$ & $0.16 \pm 0.03$ & \\
\hline & & July 20,2020 & Less than 0.1 & Less than 0.1 & \\
\hline & & August 31,2020 & Less than 0.1 & Less than 0.1 & \\
\hline & & $\begin{array}{c}\text { September } 21, \\
2020\end{array}$ & Less than 0.1 & Less than 0.1 & \\
\hline & & October 13,2020 & $1.39 \pm 0.28$ & $1.41 \pm 0.28$ & \\
\hline \multirow{6}{*}{$\begin{array}{l}\text { Phospha } \\
\text { tes } \\
\text { (by P) }\end{array}$} & \multirow{6}{*}{$\mathrm{mg} / \mathrm{dm}^{3}$} & May 20,2020 & $0.12 \pm 0.02$ & $0.18 \pm 0.03$ & \multirow{6}{*}{$\begin{array}{c}\text { Non- } \\
\text { standard }\end{array}$} \\
\hline & & June 19,2020 & Less than 0.05 & Less than 0.05 & \\
\hline & & July 20, 2020 & Less than 0.05 & Less than 0.05 & \\
\hline & & August 31,2020 & $0.15 \pm 0.02$ & $0.14 \pm 0.02$ & \\
\hline & & $\begin{array}{c}\text { September } 21 \text {, } \\
2020\end{array}$ & $0.13 \pm 0.02$ & $0.11 \pm 0.02$ & \\
\hline & & October 13,2020 & $0.10 \pm 0.02$ & $0.11 \pm 0.02$ & \\
\hline
\end{tabular}

The content of bicarbonate ions averaged $977.1(603.42-1091.90) \mathrm{mg} / \mathrm{dm}^{3}$. The main source of bicarbonate and carbonate ions in surface waters are the processes of chemical weathering and dissolution of carbonate rocks such as limestone, marl, dolomite, and geologically the considered area is mainly composed of limestone of the Carboniferous age (Chernyaeva L. E., Chernyaev A. M., Eremeeva M. N. Hydrochemistry of lakes. - L.: Gidrometizdat, 1977. -336 p.).

With a range from $571.0 \mathrm{mg} / \mathrm{dm}^{3}$ to $987.0 \mathrm{mg} / \mathrm{dm}^{3}$, the average content of sulfates was $696.22 \mathrm{mg} / \mathrm{dm}^{3}$ (Table 2), i.e., there is an excess of the maximum allowable concentration (MAC) standards by 5.7-9.9 times, which contributes to the deterioration of the organoleptic water properties. The primary source of sulfates in surface waters is chemical weathering and dissolution of sulfur-containing minerals, which are significantly influenced by redox processes.

Chlorides are the predominant anions in highly mineralized waters, namely, the water of Lake Gorkoye, in $100 \%$ of samples of which the chloride content exceeds the MAC standards by 17.1-20.7 times and is on average $5,695.79 \mathrm{mg} / \mathrm{dm}^{3}(5,140.25-6,213.08)$ (Table 3). Chlorides have a high solubility and are present in all natural waters, mainly in the form of calcium, sodium, and magnesium salts; as shown by the study, the content of sodium and magnesium ions is more than $50 \mathrm{mg} / \mathrm{dm}^{3}$. At the same time, the content of sodium ions is 2.4 times lower than the standard, and the content of magnesium ions is $1.25-8.82$ times higher 
than the standard and averages $146.72 \mathrm{mg} / \mathrm{dm}^{3}$ with a range of more than 50.00 to 352.64 $\mathrm{mg} / \mathrm{dm}^{3}$, but most likely the high content of magnesium ions is due to natural causes - the geological structure [8].

In the lake water, the number of potassium ions in all sampling periods was at the level of more than $50 \mathrm{mg} / \mathrm{dm}^{3}$ and did not meet the fishing MAC standards (Table 2). The total concentration of sodium and potassium ions was also high $-2,142.15 \mathrm{mg} / \mathrm{dm}^{3}$. The opposite pattern was observed for calcium ions - $24.31(10.84-38.08) \mathrm{mg} / \mathrm{dm}^{3}$, only 0.14 MAC.

The quality of natural water determines the presence of biogenic element ions in it [9]. Based on the average content of detected ions for the entire period from May to October and all sampling points, the following increasing series can be constructed, $\mathrm{mg} / \mathrm{dm}^{3}$ : $\mathrm{PO}_{4}{ }^{3-}$ $(0.103)<\mathrm{NO}_{2}{ }^{-}(\mathbf{0 . 1 1 9})<\mathrm{NO}_{3}{ }^{-}(0.338)<\mathrm{NH}_{4}{ }^{+}(\mathbf{1 . 1 5 3})$. The content of phosphate and nitrate ions is within the normal range (Table 4$)$. In $41.7 \%$ of the samples, the excess of the content of ammonium cations was 1.1-1.8. The content of ammonium in reservoirs with different degrees of pollution is shown in Table 3.

Table 3. The content of ammonium in reservoirs with different degrees of pollution (http://icolog.ru/gidrosfera/ammoniy-v-vode.htm).

\begin{tabular}{|c|c|}
\hline Degree of pollution (water body classes) & Ammonium nitrogen, $\mathbf{~ m g / d m}$ \\
\hline Very clean & 0.05 \\
\hline Clean & 0.1 \\
\hline Moderately polluted & $0.2-0.3$ \\
\hline Contaminated & $0.4-1.0$ \\
\hline Polluted & $1.1-3.0$ \\
\hline Very polluted & $>3.0$ \\
\hline
\end{tabular}

Based on the data in Tables 2 and 3, the water of Lake Gorkoye belongs to the dirty water class in terms of the content of ammonium cations. The increased concentration of ammonium ions can be used as an indicator that reflects the deterioration of the sanitary condition of the water body, indicates fresh pollution, and the proximity of the source of pollution (municipal wastewater treatment plants, industrial waste sumps, livestock farms, accumulations of manure, nitrogen fertilizers, settlements, and campsites) [10].

In $33.3 \%$ of the samples, there is an increased content of nitrite ions; the maximum content was recorded in May (SS No. 2) of $0.421 \mathrm{mg} / \mathrm{dm}^{3}$ or 5.3 MAC. Nitrites are an intermediate step in the chain of ammonium bacterial oxidation processes to nitrates. The increased content of nitrites indicates an increase in the decomposition of organic substances under conditions of slow oxidation of $\mathrm{NO}_{2}$; this assumption is confirmed by the ratio of nitrite ions and ammonium cations calculated during the study, which is 1.00:9.69, which means that in the conditions of Lake Gorkoye, the processes of mineralization of organic substances to nitrates are much slower than the reduction to ammonia. The presence of increased content of nitrites in the analyzed water indicates water contamination. It is crucial to monitor the level of nitrite ions in the water for fisheries; as nitrates weaken the immunity of hydrobionts and contribute to the development of various bacterial infections and reactions with hemoglobin, fish begin to die from suffocation.

Seasonal fluctuations in the content of nitrites are characterized by their absence in winter and their appearance in spring during the decomposition of inanimate organic matter. The highest concentration of nitrites is observed in late summer; their presence is associated with phytoplankton activity (the ability of diatoms and green algae to reduce nitrates to nitrites has been established). In autumn, the content of nitrites decreases.

It is recommended for natural low-polluted waters to determine the permanganate oxidability (index); in more polluted waters, the dichromate oxidizability (chemical oxygen demand - COD) is determined. According to the COD indicators, the degree of water pollution is the following: very clean - up to $2 \mathrm{mg} / \mathrm{dm}^{3}$; relatively clean $-3 \mathrm{mg} / \mathrm{dm}^{3}$; 
moderately polluted $-4 \mathrm{mg} / \mathrm{dm}^{3}$; polluted $-15 \mathrm{mg} / \mathrm{dm}^{3}$ and above. The COD value will be higher for the same samples than the BOD (biochemical oxygen demand) value since more substances undergo chemical oxidation. The ratio between these two indicators reflects the completeness of the biochemical oxidation of substances in the waters; the greater the difference between these indicators, the greater the increase in biologically active masses. The optimal range of the BOD and COD ratio is from 0.4 and up to 0.75 units. The optimal value for the ratio between COD and BOD is 0.7 , at which the biological purification process can fully occur. The conducted studies showed that the content of BOD in the lake water $\left(\mathrm{BOD}_{5}\right)$ in $100.0 \%$ of the samples does not correspond to the fisheriy MAC standards (Table 2.4 ), exceeding the indicator by $1.2-687 \%$ (9.97 with a span of $2.33-13.74)$. The increased content of $\mathrm{BOD}_{5}$ is associated with the entry of easily oxidized organic matter into the reservoir from the catchment area. Exceeding the $\mathrm{BOD}_{5}$ indicator indicates the high pollution of the reservoir - the oxygen level decreases sharply, which leads to water unsuitability (Guidelines for Hydrobiological Monitoring/Ed. by V. A. Abakumova. - SPb, 1991 - 320 p.). According to the $\mathrm{BOD}_{5}$ indicator, the Lake Gorkoye water is characterized as dirty and very dirty.

Table 4. $\mathrm{BOD}_{5}$ value in water bodies with different degrees of contamination (http://wwtec.ru/index.php?id=210).

\begin{tabular}{|c|c|c|c|}
\hline $\begin{array}{c}\text { Degree of pollution } \\
\text { (water body classes) }\end{array}$ & BOD $_{\mathbf{5}}$ & $\begin{array}{c}\text { Degree of pollution (water } \\
\text { body classes) }\end{array}$ & BOD $_{\mathbf{5}}$ \\
\hline Very clean & $0.5-1.0$ & Contaminated & $3.0-3.9$ \\
\hline Clean & $1.1-1.9$ & Polluted & $4.0-10.0$ \\
\hline Moderately polluted & $2.0-2.9$ & Very polluted & $>10.0$ \\
\hline
\end{tabular}

The permanganate index (COD) was $20.84(3.36-36.80) \mathrm{MgO} / \mathrm{dm}^{3}$. The revealed $\mathrm{COD} / \mathrm{BOD}$ ratio is $20.84 / 9.97$ and is equal to 2.09 , which means that the process of biological purification cannot fully occur.

\section{Conclusions}

1. The conducted physical and chemical analysis of water in Lake Gorkoye allows stating that water $\mathrm{pH}$ characterizes water as slightly alkaline and alkaline, water saturation with dissolved oxygen is within the norm for water fishery use.

2. The low content of sodium $\left(\mathrm{Na}^{+}\right)$, calcium $\left(\mathrm{Ca} 2^{+}\right)$, and bicarbonate $\left(\mathrm{HCO}_{3}{ }^{-}\right)$ions and the super-high content of chlorine $\left(\mathrm{Cl}^{-}\right)$, sulfate $\left(\mathrm{SO}_{4}{ }^{2}\right)$, magnesium $\left(\mathrm{Mg}^{2+}\right)$, and potassium $\left(\mathrm{K}^{+}\right)$ ions correspond to the chemical reactions of salty lake waters.

3. The excess of the norms of ammonium cations and nitrite ions, with normal levels of phosphate and nitrate ions, suggests that water in Lake Gorkoye belongs to the dirty water class, which is confirmed by the calculated ratio of nitrite-ions and ammonium cations (1.00:9.69) and indicates that under conditions of Lake Gorkoye, mineralization of organic substances to nitrate is much slower than ammonia reduction.

4. The revealed $\mathrm{COD} / \mathrm{BOD}$ ratio is equal to 2.09 , indicating that the biological purification process cannot fully occur.

5. Lake Gorkoye is in an unstable state directly caused by business activities in the surrounding area. For a complete assessment of the level of sustainability, regular studies are needed to identify the impact of ongoing climate changes on the lake ecosystems of the Southern Urals subject to negative anthropogenic impact. 


\section{References}

1. S.F. Likhachev, A.R. Sibirkina, D.Y. Dvinin, G.A. Voitovich, Water Resources 46, 290297 (2019) DOI: 10.31857/S0321-0596463290-297

2. V.A. Rumyantsev, A.V. Izmailova, Herald of the Russian Academy of Sciences 89, 1033-1043 (2019) DOI: 10.31857/S0869-587389101033-1043

3. V.I. Danilov-Danilyan, E.V. Venitsianov, G.V. Adzhienko, M.A. Kozlova, Herald of the Russian Academy of Sciences 89, 1248-1259 (2019) DOI: 10.31857/S0869587389121248-1259

4. O.V. Taseiko, V.V. Moskvichev, D.A. Chernykh, Water Resources 46, 638-637 (2019) DOI: $10.31857 / \mathrm{S} 0321-0596466638-637$

5. O.Y. Drozdova, S.M. Ilina, N.A. Anokhina, Water Resources 46, 43-50 (2019) DOI: 10.31857/S0321-059646143-50

6. A.V. Soromotin, A.A .Kudryavtsev, A.A. Efimova, Geoekologiya. Inzhenernaya geologiya gidrogeologiya geokriologiya 2, 48-55 (2019) DOI: $10.31857 /$ S086978092019248-55

7. E.V. Borodina, U.O. Borodina, Water Resources 46, 405-416 (2019) DOI: $10.31857 /$ S0321-0596464405-416

8. V.P. Shesterkin, M.I. Afanaseva, N.M. Shesterkina, Geoekologiya. Inzhenernaya geologiya gidrogeologiya geokriologiya 3, 42-51 (2019) DOI: $10.31857 /$ S086978092019342-51

9. V.I. Radomskaya, N.A. Borodina, Inzhenernaya geologiya gidrogeologiya geokriologiya 6, 79-93 (2019) DOI: 10.31857/S0869-78092019679-93

10. S.S. Ulanova, N.M. Novikova, Water Resources 46, 629-637 (2019) DOI: 10.31857/S0321-0596466629-637 